\title{
Shakespeare and Early Modern Religion, edited by David Loewenstein and Michael Witmore
}

Cambridge: Cambridge University Press, 2015 | 317 pages | ISBN: 978-I-I07-0266I-2 (hardcover) £69.99| ISBN: 978-I-I0873366-3 (softcover) £22.99 | ISBN: 978-I-3 I6-23603-I (ebook) $\$ 24.00$

This book arrives as a counterpart to Shakespeare and Early Modern Political Thought (2009), both "collaborative" works seeking to contextualise Shakespeare's

Shakespeare and Early Modern Religion

David Loewenstein and

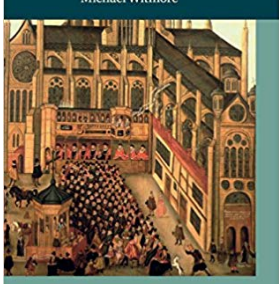
oeuvre against the backdrops of religion and politics. ${ }^{1}$ Not an intentional constituent of the anniversary year publications, it is nonetheless "of its time," insofar as the authors explicitly situate their work within the stream of recent Shakespeare scholarship-itself responding to shifts in the historiography of early modern religion—as well as reinterpreting the religious aspects of

${ }^{1}$ It is a minor disappointment to this reader that the list of contributors is less "international" than its antecedent (all authors are based in British or North American institutions), while the imbalance of male and female contributors has increased. This might have passed without remark, were the internationality of the volume not part of its promotional text. 
Shakespeare's work according to current understandings of the late sixteenth and early seventeenth century. The presence of two timelines (that of scholarship, and that of Shakespeare) means that this work may be interpreted as reception history on multiple levels.

It touches upon the reception history of "Shakespeare as religious," noting first the longstanding convention that the playwright was not preoccupied by religion, while also outlining (briefly) the arguments put forward in the late I990s for his Catholicism within David Bevington's essay (chapter I). Happily, this is not a collection that seeks to determine Shakespeare's own beliefs. Rather, "the chapters ... eschew firm or reductive assertions about Shakespeare's personal religious convictions" (I). The work as a whole is divided into two parts: chapters $\mathrm{I}-3$, "Revisiting Religious Contexts in Shakespeare's England"; and chapters 4-I 4, "Representing Religious Beliefs and Diversity in the Plays."

Following on from the Introduction, the principal occupation of Bevington's essay is with the nuances of early modern religion invoked within the plays: judging from the Puritanism figured in Twelfth Night, All's Well that Ends Well, A Winter's Tale, Pericles, and Henry IV, Part I, the playwright is found to be non-didactic, yet possessing a specific "antipathy" toward those inclined to suppress the theatre on moral grounds (28). Hamlet, King John, and Henry VIII (each of which receive further consideration from other contributors) are read with generational interplay reflective of a sixteenth-century reality: behind each reformer was a Catholic parent. Brief discussion of other Histories highlights particularly the balance of Henry $V$, the monarch at once "Catholic in his royalty and Protestant in his theology, ... an absolute monarch with the democratic touch" (39).

In chapter 2, Peter Marshall picks up the late Patrick Collinson's suggestion that the English Reformation was realised in Shakespeare's lifetime (43). It is all too easy to read this period as if the break with Rome was known to be lasting; yet the reigns of Edward and Mary Tudor were evidence of how quickly tides could turn-and how undecided matters actually were. With a host of examples from Shakespeare's home county of Warwickshire, Marshall illustrates the unsettledness of England's religious allegiance and the corresponding "impulse to discussion and debate ... at the heart of the religious culture of Shakespeare's age" (52). He thus moves the context for interpreting Shakespeare's engagement with religion away from the supreme conquest narrative (forwarded by John Foxe \& co.) through the revisions of Duffy, into the post-revisionism of Walsham.

Chapter 3 shifts attention from Warwickshire to London, as Felicity Heal 
surveys the strands of Christianity preached and practised in and around Shakespeare's parish in this period. The urban setting did not facilitate tight enforcement of establishment requirements vis-à-vis church attendance; evidence shows that a regular rural worshipper might become a sermon tourist given urban opportunity-with Heal gently urging the reader not to conclude too much from Shakespeare's invisibility in parish records. Among Shakespeare's known associates was a (former?) member of the French Stranger Church, a body that (with its Dutch counterpart) had been looked to as a model by Cranmer under Edward VI. At the same time, London in Shakespeare's time (especially into James' reign) hosted an increasing Catholic recusant presence, as revealed by a "makeshift chapel" in the French embassy, whose deadly collapse was precipitated by a crowd of more than 300 congregants (72).

Alison Shell opens part II with a close study of A Midsummer Night's Dream, attempting to resolve the paradox that the play's happy ending requires Demetrius to remain in essence deluded. Shell's argument is complex in composition, taking a mention of "Himera, the worthy Stesichorus his idol" in footnotes to Edmund Spenser's The Shepheardes Calender (I 579) as inspiration for Shakespeare's distractive Hermia, whose attractions Oberon's spell dispels. While "Himera" is a chimera, an accident of Greek mistranslation, in early modern understanding it was this woman who prompted the poet to scorn Helen(a) of Troy, Stesichorus excusing himself on account of having seen and judged not Helena but her eidolon. Is it, therefore, the real Helena whom enchanted Demetrius finally courts, or an idol? Lysander-a victim of Puck's magic_-accuses himself of "heresy" (2.2.I47; p. 87) having earlier described how Helena "dotes in idolatry" on Demetrius (I.I.Io9; p. 89). Together such references, Shell suggests, "teasingly [allude] to contemporary Protestant concerns about misdirected worship" (90). Developing a separate line of argument, she also interprets the role of the fairies as both an implied critique of "liturgical nostalgia" and a source of false circular guidance loosely associated with Catholic error (94). Puck's apology, in this reading, is not quite serious (95).

While for the most part an account of Shakespeare as a receiver of (and his texts as a channel for distributing) early modern religious currents, there are elements within this volume that might find a home in a collection on the reception history of religious texts. One such is found in Beatrice Groves's treatment of King John (chapter 5), where we learn how the critical difference between Josephus and the Josippon-the Hebrew Jewish War preferred in the 
sixteenth century as his "Jewish" edition (IO4)—facilitates the Bastard's approach to Angiers' siege. By playing with different constructions of the defence (and fall) of Jerusalem - and more specifically the unity or disunity of Jewish forces within the city, Groves's Shakespeare introduces "the oppositional idea that those who rebelled against conformity [viz. the Bastard] need not be feared as enemies to the public good" ( 1 I 0 ), that loyalty and nonconformism could cohabit in the newly island-bound England. ${ }^{2}$ Groves's work is clearly argued, and enters a formerly unmapped biblical reference "even with the ground" (King John 2.I.399 // Luke 19:44) in the concordance of Shakespeare's Bible.

If there is no Christian God in Julius Caesar, Peter Lake argues (chapter 6), it is not only that the play so cleverly presents the "classical republican" or "neo-Roman" perspective through the eyes of those who plot Caesar's murder to protect their republican ideal (in Skinnerian terms, I II). For what arises thereafter (tyrannical empire) is itself a rejection of that ideal, repudiating it. In addition, the repeated inattention of characters to the various supernatural signs and portents — which yet prove accurate-indicates that their viewpoint is not something to emulate. Whether or not Shakespeare's temporally distant subject matter was a response to the censorship of English histories (and Lake is non-committal on this point), the Christian audience would find themselves required to "attend to the warnings, admonitions, and judgments of divine providence," "to remember that they were Christians" (I30).

In chapter 7, Adrian Streete uses Lucretius's De rerum natura to shed light on Measure for Measure, identifying ways in which the Epicurean philosopher was received within early modern intellectual culture in spite of his potent challenges to Calvinist theology. "[I]n its discussion of natural law, religion, and sex," Streete argues, "Measure for Measure dramatizes a Calvinistic world becoming Lucretian" (I 33). That Angelo epitomises an outward Puritanism, visibly corrupted by his lust for the novice Isabella is well established. Streete adds a further dimension, connecting the "hooked" atoms of Lucretius's physics, "which therefore tear their way into our senses, and entering break the surface of our bodies" (DRN II.40 5-7) with Isabella's description of Angelo's hypocrisy, "hooking both right and wrong to th'appetite" (2.4.175; p. I48). Subsequently Isabella's vocabulary is seen to parallel Lucretius's conception of sex, a "stooping" that recurs in Angelo's final sentencing (5.I.4I3,

${ }^{2}$ As Groves observes, "the Elizabethans were the first generation of Englishmen without any claims on mainland Europe" (99). 
I 52). Taken together with the discomfiting marriages that conclude the play, we find at once "a wry comic reflection" on I Corinthians 7:9 ("better to marrie than to burne", cf. p. I 52) and the suggestion that a politics (or theology) that does not take account of human sexuality will fail (I 54).

King Lear and agnosticism are David Loewenstein's focus (chapter 8), the play "set in a pre-Christian world" (155) involving appeals to the divine and yet no corresponding reassurance or providential intervention. This non-providential space sits at odds with the universe propounded by Thomas Beard and other Calvinist contemporaries, visions "of heavenly anger and severe vengeance justly executed against brazen malefactors from Hebrew times to the present" ( 158 ) or the brutality presented in John Foxe's woodcuts. As a dramatist, Shakespeare (argues Loewenstein) had a particular freedom to explore radical ideas (I62), with "an ideological eclecticism" (I 68). The dark climax of Shakespeare's play is very different to that of his source, The True Chonicle History of King Leir (publ. I605) where justice triumphs with the restoration of Leir, and his reunion with "Cordella" at the hand of the Gallian King (I69). Shakespeare's shocking deviation from that Job-like happy ending supports Loewenstein's inquisition: "What if there might indeed be no providential order governing a pitiless world ... ?" (I 70)

Ewan Fernie's essay (chapter 9) has a decidedly different feel to others in this collection, a study of Macbeth that interprets the play's diabolical dimension as an outworking of Luther's thought. Here we find Luther reading Augustine, and Fernie reading Dostoevsky, Yeats, and John Milbank (with Dali and El Greco for visual inspiration) — an experience not unpleasurable. This Luther has a toilet humour coupled with whole-hearted belief in his dependency on grace; citing exchanges with Melanchthon and Jerome Weller, and then reflecting on Marlowe's Faustus, Fernie communicates the risk underpinning this grace: "if [the Reformation] leads into the cloaca, we might, perversely, discover that we like being there and choose a life of sinning bravely not as a cry to God to intervene, but rather for its own sake" (I 82). The Reformation road to salvation "equally forks into Hell"—or Scotland, as Fernie interprets Macbeth, a hell unalleviated by the supernatural (I 88); this, we are invited to consider, is what it means to "memorize another Golgotha" (I.2.40), an "abortive Protestantism" with "no rising but crucifixion alone" (190).

Co-editor Michael Witmore writes about Shakespeare and "wisdom literature” broadly conceived (chapter Io), moving from Steven Marx’s reading of Shakespearean tragedy as itself wisdom literature (I9I-92) to a questioning of the forms of wisdom literature available to the early modern audience. 
Within this conceptual space Erasmus's adages sit alongside biblical proverbs, both turned to after the manner of Augustine's vision: take up, read, wherever the book opens. The formalisation of lottery-style reading is mimicked then in the casket lottery of The Merchant of Venice, and the process Lear adopts to allocate his lands-corresponding with the original lot allocations of Numbers 26. Read in this context, Lear's fool is "an oracle without divinity" (2 I0). Stepping back without the plays, Witmore considers the hypothesis that the names were themselves a kind of parodic lottery, as the theatre-goer had little information to choose between All's Well that Ends Well, As You Like It, and What You Will.

In chapter I I, Richard McCoy discriminates between varieties of faith in a study prompted by the denouement of The Winter's Tale: when Paulina requires Leontes to "awake your faith," a command that calls upon the audience also ("your" not "thy"), what kind of faith is to be awoken? In the dramatic narrative, this is something of a trick: the wronged and rescued Hermione is restored to the penitent Leontes in the form of a seeming statue; faith is required to "make the statue move, indeed descend" (5.3.89, 94; p. 214). So are miracles tricks? Should the audience infer a religious judgment? "Like all Shakespeare's late plays," McCoy remarks, "The Winter's Tale is suffused with hints of higher, supernatural forces at work behind both its painful and felicitous reversals" (2 I4). The audience never learns how Paulina has secured Hermione through the intervening years. But it is to Coleridge that McCoy turns for his hermeneutic: a reader of Donne, Luther's Table Talk, and a devotee of the Book of Common Prayer, Coleridge identified "good will" as a point of convergence, a prerequisite for both "poetic and religious faith" (217). Set against the backdrop of competing interpretations of the Eucharist, and understood especially through the via media of Calvin's semiotic efficacy, the faith that awakens Hermione is kin to but distinct from the religious awakening.

Chapters I 2 and I 3 both engage with one of Shakespeare's lesser known works, Henry VIII (I6I3), co-written with John Fletcher the subsequent "chief playwright of the King's company" (Gordon McMullan, cf. p. 24I). Paul Stevens (chapter I2) presents Henry VIII as a counterpoint to the individualism of Hamlet (seen through the critical eyes of secularist Harold Bloom and post-secularist Charles Taylor). With a corporate liturgical tone, the controlled exegesis of this schismatic episode in England's religious history brings the audience "together in a godly unity to experience the presence of God's grace in the history of their national community" (240-4I). The competing narratives of Henry's conversion occupy Michael Davies in 
chapter I 3: is it Anne who prompts his "prick" of religious conscience, or "th' Bishop of Bayonne" who suggests the impropriety of his marriage to Queen Katherine? Locating Shakespeare's source-George Cavendish's life of Wolsey, mediated by Stow and then Holinshed—allows Davies to examine how Shakespeare has treated this material, and indeed how all but Cavendish (a Catholic) shift the depiction of Henry from clear hypocrite to a position of uncertainty. Shakespeare's conversion scene takes up the evangelical trope, the contrast of "historical faith" (received) and "felynge faith" (experienced) derived from Melanchthon and communicated in the exchange between Tyndale and Thomas More. Though Henry's position as reformer was inevitably ambiguous (given his views on justification), the ahistorical christening scene in which Cranmer declares the babe Elizabeth as fulfilling the expectation of a male heir is a sufficient testimony towards the play's purpose, conveying "transcendent Truth" (277-79), albeit atypical of Shakespeare.

The last essay (chapter I4) is the only one to give sustained consideration to the direct depiction of non-Christian religions, in essence the other Abrahamic faiths. There is something of rote about including a commentary on what is largely an absence, The Merchant of Venice and Othello being the major exceptions. Matthew Dimmock suggests that one reason for Shakespeare's reticence in handling other faiths was the legislation prohibiting representations of "superstition or idolatrie or which be contrarie to the lawes of God ..." (cf. 280-8I), while acknowledging that the plethora of "Turk plays" (which Dimmock has written on elsewhere) may have been their own disincentive. For The Merchant of Venice, Dimmock's main observation is the distinctive New Testament hermeneutic that leads Shylock toward inadvertent self-condemnation (where The Jew of Malta's Barabas was stuck citing only Old Testament texts). A strength of Dimmock's discussion is his awareness that Shakespeare's encounter with these "other" figures was mediated not only by his society but specifically "their semantics within theatrical culture" (299).

Brian Cummings's afterword effectively frames the contribution of this collection: Returning to the observation that Shakespeare has been received as a secular playwright - one whose plays never take a biblical subject as their plot (300), Cummings observes how New Historicist scholarship made space for "the power of religious languages and fantasies in early modern culture" (30I) so that with the later rejection of the secularisation hypothesis (by some) there could be a fuller "religious turn" within Shakespeare Studies (302). This volume is the fruit of that turn. 
To conclude, this is a wide-ranging and frequently fascinating series of studies. In each chapter, careful and thorough footnotes provide a sound guide to further contextual reading. The details of some arguments warrant a closer reading of the drama under discussion, and without that it can be hard to digest all that is offered. Happily, there is no compulsion to read from start to finish in one fell swoop, and the internal cross-referencing should facilitate those who wish to take their own direction in exploring its rich contents. Although the Bible is seldom the major focus of discussion, there are texts such as Hamlet's "fall of a sparrow" that receive repeated discussion, in a way that opens up different facets of Shakespeare's biblical usage. ${ }^{3}$

\author{
Iona C. Hine \\ University of Sheffield
}

${ }^{3}$ See pp. 7, 35, 77, I 57, 238-39 which together explore this blend of Matthew I0:29 with Calvin's Institutes, situating it alongside Hamlet Senior's apparent Catholicism and Horatio's scepticism, and - with Anthony B. Dawson-noting the hateful destiny awaiting the disciples despite such reassurances. 